\title{
O Sister! Sarah Palin and the parlous politics of poor white trash
}

\author{
Eliza Jane Darling
}

Published online: 24 March 2009

(C) Springer Science+Business Media B.V. 2009

A few days after the second election of George W. Bush to the US executive office, a bit of discursive flotsam entitled "Fuck the South" wound its inevitable way through the drifting currents of cyberspace and landed in my inbox. Penned by an anonymous, self-described northeasterner on an aptly named blog called "Annotated Rant," it comprised a bitter diatribe defending liberal Yankee politics against the hypocrisy of southern conservatives (Anonymous 2004). Arguing that the northeast is in practice a paragon of all the virtues - from self-reliance to patriotism to family values - the latter claim to hold dear, it posited the south as a sanctimonious, freeloading relative who should've been allowed to leave the clan more than a century ago when it threatened to disown its northern cousins over slavery. The piece didn't actually say "fuck the rednecks," but it ticked all the boxes: southern, poor, gun-toting, bigoted, jingoistic, right-wing. It concluded with a pointed swipe at the Republicans, effectively linking the GOP to poor white trash: "And no, you can't have your fucking convention in New York next time. Fuck off."

Four years later, the Angry Urban Liberal contingent turned its redneck radar north. The nomination of Sarah Palin, sitting governor of Alaska, to the Republican vice presidential candidacy sent liberal writers from the lofty offices of the New York Times to the humble laptops of bedroom bloggers on a frenetic treasure hunt for redneck aspersions, excavating the American cultural landscape for a timehonored denigrating discourse glossed by the thin veneer of hillbilly appreciation laid down by $\mathrm{O}$ Brother! Where Art Thou, the second coming of Johnny Cash, and the folk revival that ushered in the dawn of the new millennium. While America's journalists burned the midnight oil churning out wry headlines, from "McCain's Baked Alaska" (Collins 2008b) to "Palin and McCain's Shotgun Marriage" (Rich 2008) to "McCain's Grizzly Politics" (Collins 2008a) to "Northern Underexposure" (Dionne 2008) to "Sarah Palin: A Trojan Moose Concealing Four More Years

E. J. Darling (更)

Department of Anthropology, Goldsmiths College, University of London, London, UK

e-mail: ans01ed@gold.ac.uk 
of George Bush" (Huffington 2008), beneath the barrage of trite one-liners lay a bitter politics of class, gender, race and geography whose superficial jocularity was belied by the sheer resentment of Palin's detractors, not only at her policy trajectory, but at her rural backstory, and the belabored, bewildered connection between the two. Although the fevered frenzy of redneck-baiting was soon eclipsed by the financial debacle in a whiplash-inducing swing from Wasilla to Wall Street, the discursive slippage between Sarah Palin's politics and Sarah Palin's background exposed a contradiction deeply entrenched in American culture-and not for the first time on the stage of presidential politics. The conspicuous redneck backlash of the 2008 election both focused and amplified the residual hangover of political culpability that soured the air four years ago, and both emerged from the depths of a brewing storm over the constitution of American authenticity.

2004 was a red letter year for American family squabbles. The disastrous war, the ballooning deficit, and the assault on civil liberties brought the left and much of the centre to the streets in mass demonstrations, while the right, and the rest of the centre, opined about the need to sacrifice in defense of the homeland and its godgiven imperial ambitions: well-worn quarrels, but with a few new twists. Both sides laid claim to patriotism this time around. There was little flag-burning at the largest nationwide demonstrations since the Vietnam War; indeed I witnessed one scene, at the aforementioned Republican National Convention, where a small group of counter-protesters shouting USA! USA! USA! on Sixth Avenue were drowned out by several hundred thousand antiwar marchers shouting the same thing right back at them. Patriotic symbols abounded at the New York City demos: Statues of Liberty, Revolutionary War-style fife and drum bands, Uncle Sams, and everywhere, the stars and stripes - and this time, they weren't on fire. The argument wasn't about whether to defend America that year, but which America to defend, and against whom.

When Bush was elected, almost unbelievably, to a second term, a lot of people blamed the rednecks, by name or association. The heartland, the south, middle America, rural America, however it was phrased, they took the heat from the "other" America-the cities, the northeast, the east and left coasts. I sat in a bar in Brooklyn the night Kerry went down in flames and the entire place erupted in a deafening cacophony of cheers when California flashed blue, a nod to the deep political affinities which belie the usual proprietary backbiting between the competing factories of American cultural production. As the centre of the map turned blood red behind Dan Rather's greying pate, it certainly seemed as though the heartland had screwed the coasts again, but there was more to it. Geography was a proxy battleground for a fight that had far more to do with class, race and politics than with location. Nobody seriously believed that black and Latino voters put Bush back into power, regardless of where they lived. That Kerry actually won redneckriddled upstate New York by a slim margin, and that nearly a quarter of New York City voted for Bush, was beside the point. No, it was the hicks, the yokels, the biblebashing gun-loving poor white trash who sold out America. Why not blame us? Bush was one of our own, wasn't he, with his ranch and his cowboy hat and his golly-gee-shucks patois? Redneck is a conveniently malleable identity. If a multimillionaire Yale graduate from New Haven, Connecticut can earn his hayseed 
stripes in Texas, then all bets are off; redneck is as much a self-construction as an exercise in othering, geography as much an exercise in identity-building as a birthright.

"Fuck the South" is just one example of the space-hick conflation, but it's arguably the most enduring one. We, the northern rednecks, have always got short shrift in the hillbilly sweepstakes. Oh we're there, alright. Michigan, Maine, Vermont, Iowa, and of course, upstate New York, especially my own Adirondacks, are chock-a-block with yokels. My mother keeps a piece of paper in her hutch labelled "The Adirondack Questionnaire." How do you know you're an Adirondacker? A. You have at least three appliances on your front porch. B. Your favorite sports are huntin, jackin, fishin, and spittin. C. You called your firstborn "Bud Lite." D. Your wife is bigger than your pickup. I don't know where it came from but it's been there for dogs years, a local iteration of an old redneck joke that's made the rounds across rural America, the premise of which comprises the bread-and-butter of self-described redneck comedians like Jeff Foxworthy. It was always hilarious as a self-parody, our Adirondack family sitting round the kitchen table in the old days trying out-cracker each other. Still, it's probably more recognizably applicable to rednecks from the south than from the Adirondacks, which some people have never heard of, and many conflate with Appalachia. Southern rednecks are just more authentic, somehow. Maybe it's the Dixie drawl, or the religious fervor, both redneck yardsticks against which northern rubes tend to come up short. Or maybe it's an historical hangover: the term "redneck," at least as we use it today, was first applied to the inhabitants of the white rural south, and especially the Scots-Irish who came from the Highlands via Ulster to settle the hills and hollers of Kentucky, Tennessee, and West Virginia. We may have gate-crashed their party, but they're running the still, and the stream of down-home redneck authenticity continues to find its purest source south of the Mason-Dixon line.

The categories I've unproblematically elided—redneck, hillbilly, hick, yokel, hayseed, cowboy, cracker, poor white trash ${ }^{1}$-represent a set of conflations which link whiteness, rurality and poverty to backwardness and conservatism. Each bears a specific etymological identity belied by their commensurability in popular culture constructs from South Park to Trailer Park Boys, yet their latter-day rhetorical interchangeability is less interesting than their longstanding coexistence with their own collective foil: an alternative set of conflations linking whiteness, rurality and poverty to authenticity and progressiveness. The sentiments are close bedfellows, as the dawning decade of the twenty-first century has amply demonstrated. If the cultural geopolitics of 2004 were dominated by the urban liberal castigation of America's nightmarish rural dystopia in all its Deliverance-haunted anxiety, it was an about-face from the zeitgeist that had obtained just a few years earlier, dominated by the white urban liberal celebration of America's sepia toned rural idyll in all its Klinkenborgian ecstasy.

\footnotetext{
1 See Carr (1996), Harkin (2004), Hartigan (1997), Huber (1995), Jarosz and Lawson (2002), Wray and Newitz (1997), Billings et al. (1999), and Wilson (2002) for more nuanced discussions of these and related taxonomies.
} 
It was the culture industry which drove the millennial rural revival, with $O$ Brother (both a brilliant parody and self-fulfilling prophecy of the unquenchable American thirst for old-timey hillbilly authenticity) providing the lynchpin between the twin engines of Americanization, music and film, as well as the script by which white America could comfortably disentangle the politics of bigotry from rural poverty. The film's moving climax, in which the transcendence of American song trumps the entrenchment of American racism-Homer Stokes shouted down mid Klan-rant while Ma and Pa Gothic listened on the radio-allowed America to love its crackers again. "I guess folks don't mind they's integrated ... God damn, opportunity knocks!" marvelled Pappy O'Daniel in a shrewd navigation of the treacherous terrain of American racial politics, over which three ballsy hillbillies and one passive "negra" led the crowd to the promised land where harmony triumphed over injustice. As white male rural America was masterfully elevated by the plot, black male rural America was expertly emasculated: Tommy Johnson saved from his own deal with the devil (his soul for his guitar skills, both a staple of American blues folklore and, in retrospect, an odd harbinger of suspicions that Barack Obama couldn't possibly be the talent behind his brilliant speeches) by poor white trash whose suffering under the crushing boot of the American class system engendered such a natural solidarity with southern blacks that they would risk everything to save him from the noose. The Soggy Bottom Boys stood for the rural America many white Americans want to love, united by a racial mellifluousness emanating from the beneficence of the white man, an atonement for racist transgressions which nonetheless leaves racist power structures comfortably intact.

Yet the rush to embrace country trash, which swept across the landscape like a cultural twister in the wake of the $O$ Brother phenomenon, was a temporary respite in America's long-running bid to disavow its own rustic heritage. "The United States was born in the country and moved to the city," as historian Richard Hofstadter (himself no stranger to provincial-bashing) once wisely observed, and like most stroppy teenagers, continues to be hell-bent on putting as much distance as possible between itself and its anachronistic origins. America has long been at sixes and sevens over the hillbilly question. Alternately celebrated as the down-home, salt-ofthe-earth, stalwart backbone of democracy and deprecated as the ignorant, backward, benighted castoffs of progress, the white rural working class are perennially caught between veneration and denigration, both tropes acutely contingent upon the particular historical circumstances which bring them (occasionally) to the attention of an increasingly nonrural America. This duality is bound up with America's uneasy struggle to come to terms with its own identity, temporal and spatial. As Anthony Harkin notes in his historical account of the hillbilly icon, hillbillies "....served the dual and seemingly contradictory purposes of allowing the 'mainstream,' or generally nonrural, middle-class white, American audience to imagine a romanticized past, while simultaneously enabling the same audience to recommit itself to modernity by caricaturing the negative aspects of premodern, uncivilized society" (Harkins 2004, p. 7). Little has changed. It's a relationship of resentment and reassurance; mainstream America is just not that into us, until it hits an identity crisis, and comes home to the country, over the river and through the woods, to nurse its raw urban wounds. But rural America is not merely contradictory in the cultural 
constructions deployed by its erstwhile foil. Historian Stock (1996) notes an uneasy, dualistic revolutionary politics deeply ingrained in the fabric of rural America itself, a place as complicated from the inside as from the outside. The rural American radical is both Daniel Shays and Timothy McVeigh, but Stock lionizes neither and acknowledges the impossibly complex politics of both. "Perhaps the neat categories were meant for somebody else," she says (1996, p. 13), and the 2008 presidential election brought America's cultural housekeepers out in droves. Sarah Palin was an easily pigeonholed redneck, and few were interested in disentangling her right-wing politics from her small-town background. It was taken as given they go together, though why that might be the case, or what might be done about it, remained a mystery blithely unplumbed by most liberal pundits.

Slate magazine, for example, published a cryptic video (Slate 2008) entitled "Postcards from Palin's Hometown," describing Wasilla as a place "to get gas and pee before heading farther north to Denali or Fairbanks." It's really, really rural, Slate informed us - "it takes just about six minutes to drive from one end of town to the other!"-but it's not pleasingly rural: "You hear that Palin was the mayor of a small town and you think of central squares and tree-lined sidewalks and neighbours who give pies to one another, but Wasilla isn't that kind of place. It's more like Fort Worth without the glamorous bits, or Myrtle Beach without the college kids, or the beach." And if Slate's trenchant pie-economy analysis wasn't enough to convince you that Wasilla isn't the right sort of rural (i.e., the kind constructed for the benefit of Antiques Roadshow refugees), they also noted that Wasilla is littered with heavy equipment, four-wheelers, haphazard shacks and box stores, thanks to its aversion to zoning ordinance. In other words, Wasilla is scrubby, plain and functional: windshield tourists, clutch your copy of Martha Stewart Living to your hearts and drive on. The chino-clad reporter's sole encounter with the locals seems to have been an incident in which a truck full of "roughs" told him to fuck off (a sentiment I wholeheartedly shared), so the film wasn't really about getting to know the town or its inhabitants beyond a few cursive shots of Wasilla's geography of nowhere. So what was the point? A generous interpretation might conclude that Sarah Palin's small-town upbringing saddled her with a lamentable lack of experience. "Sarah Palin got her first passport in 2007," we were informed in hushed tones. But the narrator's subsequent invocation of Dick Cheney and George Bush as paragons of vice presidential fitness prompts some rather sticky questions about the efficacy of political sophistication.

Despite a few references to Palin's actual policies, the bulk of the video was about her small-town lineage. If she were more urban, more worldly, more experienced, it seemed to say, she'd be more qualified. This may have been a cleverly calculated zinger intended to expose the hypocrisy of relentless Republican attacks on Democratic presidential nominee Barack Obama's credentials, but the crafted ambiguity of the film's subtle condescension made it difficult to tell. Which, I suspect, was precisely the intent. Several of Slate's forum posters got the message. One spotted the class implications immediately: "As a life long resident of Fairbanks, Alaska, I couldn't help but feel angered at this condescending portrayal of Wasilla...Yes, this is the sort state where there are many communities without any zoning. The kind of place where a nice neighborhood with its own private air 
strip and fleet of privately owned planes will be flanked by a junk yard. The kind of place where finding ways to pinch pennies is one of our favorite hobbies, and yes, the kind of place where the opening of a new discount store is a huge deal." Another took issue with the purposeful ambiguity: "I appreciate being able to see the town where our next VP might be coming from. You could have done it fine without all the sarcastic, snide innuendo...How about just stepping up and saying what you really mean to say. Don't hide it in vague references and snotty toned commentary as you waltz around this town all arrogant and superior feeling."

If Slate was coyly oblique in its redneck characterization of Sarah Palin and her hometown, others exhibited no such reservations. Maureen Dowd, Pulitzer-lauded craftsman of cutesy quips, called her a "gun-toting hockey mom" and "two-year governor of an oversized igloo" while harping on her Miss Congeniality prize from a 1984 beauty pageant and upbraiding her for buying her daughter's cheerleading kit on the day she got the nod from McCain (Dowd 2008). Gail Collins, not to be outdone in the sister-slamming stakes, referred to her as "the moose-gutting, polarbear trashing, aerobics-class networking vice presidential nominee" (Collins 2008c) and looked forward "to deconstructing her role in the Matanuska Maid Dairy closing crisis" (Collins 2008b). Below the radar of national broadsheets, the blogosphere was awash with white trash epithets, many of them pointedly gendered. A poorly photoshopped mock-up of Sarah Palin in a red, white and blue bikini brandishing an assault rifle made the cyberspace rounds just days after the nomination, and Palin was described as a MILF_- "Mother I'd Like to Fuck," conjuring images of sleazy housewife pornography—on YouTube along with dozens of blogs and message boards. For true devotees, commodities bearing such slogans as "MILF/McCain 08" and "Maverick \& MILF" were available on multiple sites in t-shirt, trucker hat and coffee mug form. In the ultimate spirit of hypersexualization, Palin was compared to America's most notorious poor white trash icon, Britney Spears. And of course, the rumor which purportedly prompted Palin to reveal the pregnancy of her 17-year-old daughter, Bristol, played mercilessly upon the cliché of tortuous redneck kin relations and promiscuity: Trig, Sarah Palin's youngest child, was alleged by Daily Kos to be Bristol's son, adopted by grandma in order to avert scandal. The original blog entry, since pulled, was littered with sick-making close-ups of the two women's abdomens and heated speculation about when, precisely, Sarah Palin's water broke for the (allegedly!) fifth time.

Palin's redneck identity became, in such constructs, a marker of dysfunctionality through which her conservative politics could be attacked on the same basis as "Fuck the South"-through accusations of hypocritical posturing belied by alternative "realities." Her self-construction invoking genuine rural authenticity became a ready-made foil for the liberal counter-construction, invoking dystopic rural pathology in a clash of discordant tropes: the folksy Rockwellian countryside marred by the unsightly spectacle of ramshackle rural poverty, down-home commonsensical wisdom discredited by parochial ignorance of the world, the good mother debunked by the vaguely incestuous trailer trash slut. She became less a collection of policies than a collection of symbols. And through Palin was all of white rural America essentialized and indicted, aided and abetted by its own widely 
circulated expressions of bigoted right-wing hatred: Obama effigies hung from trees in Oregon and Kentucky, small-town gatherings evincing suspicions about Obama's Muslim heritage, demonstrations articulating rage against the very idea of a black American president.

The coupling of redneck and right-wing politics is a marriage with a long and complex kinship. Conservatism in white rural America, south and north, is no mere fiction of redneck stereotyping, but an entrenched condition deeply embued with what historian Alex Saxton calls the racism of "herrenvolk democracy," a white supremacist ideology which, as sociologist Pierre van den Berghe argued, originated in the European colonization of the New World as a legitimization of plantation slavery which survived slavery's demise and continued to dominate American labor politics with the rise of industrial capitalism (Saxton 1990). Its most important political watershed lies in the Democratic loss of the "solid south," an enduring legacy of Truman's bid to hitch the wagon of the party to the star of the civil rights movement, which opened the space for the exploitation of herrenvolk racism in the subsequent Republican "southern strategy." If its obstinate historical protraction is thanks in no small part to the concerted ideological efforts of the right, from Nixon to Rove, to muster white working-class rurality to the banner of the GOP, it must also be attributed to the Democratic tendency to swallow the redneck bait dangled by clever conservative ideologues seeking to exploit the self-made weaknesses of the neoliberal left's dubious class commitments. "White trash America certainly has allure for voters," wrote Erica Jong with a mixture of incredulity and indignation in the Huffington Post. "Some people think rednecks are more American than Harvard educated intellectuals of mixed race" (Jong 2008). That this comes as news to the left should give us considerable pause. Aside from the sheer hypocrisy of trailertrash baiting by that wing of the American political establishment which once claimed to stand for the poor, the downtrodden, the unemployed and the oppressed, the failure to appreciate the Jeffersonian significance of small-town America to the US territorial imaginary (Feldman 2005) was an astonishing tactical blunder, and contributed to Barack Obama's "Appalachia problem," which was ultimately overcome by the mobilization of an alternative vision of American authenticity deeply rooted in its multiracial immigrant past, but not, by a long shot, mitigated at the source.

While the failure to avoid the bear trap laid cleverly by the McCain-Palin ticket resides deservedly at the feet of the mouthy Democratic rank-and-file, who shoved their greedy heads like Winnie-the-Pooh into the heffalump's honey pot, the party leadership made its own mistakes. Barack Obama, who otherwise (particularly in his passionate if short-lived defense of Reverend Wright) demonstrated a nuanced and articulate understanding of white working-class anxieties, uncharacteristically blundered into caricature via his ill-advised comment linking the "bitterness" engendered by small-town unemployment to guns, religion, anti-trade and antiimmigration sentiment. Like most caricatures, it both resonated and backfired because it mingled a certain degree of truth with unproven consequence. Rural America has good reason to be bitter, that's true enough. Decades of decline, depression and deindustrialization have been offset only in those areas of counterurbanization bolstered by the influx of upper-class exurbanites seeking a 
piece of Arcadian paradise on the margins of a primarily urban and suburban American society. It's a litany of sorrow familiar, in many ways, to both sides of the rural-urban and white-black divide. White rural poverty and black urban poverty are not identical, but they share certain characteristics in common. Both occupy the most culturally visible reaches of the lowest rung on the American food chain, to a certain extent obscuring the harsh realities of white urban poverty, black and Latino rural poverty, and the utter devastation of economic immiseration on American Indian reservations (another facet of rural America alternately venerated and denigrated, when considered at all). Both are associated with entrenched images of sexual violence, workshy indolence and substance abuse; both fall victim, under similar structural circumstances, to the brutalizing forces of gentrification; both are object of a plethora of vicious stereotypes casting women as immoral, promiscuous, overbreeding bottom-feeders and men as thuggish, pig-thick, lazy animals; both stand accused of leeching the life out of the American dream by their abject failure to pass the hallowed bootstrap test. The crack-whore welfare mother and the gangbanging drug-pusher in the ghetto, the meth-head trailer-trash slut and the drunken wifebeater in the sticks; America hates, fears, and sexualizes them all. Neither being equal nor identical histories in racial or gendered terms, they nonetheless share in common a certain cultural functionality, to be trotted out as cautionary tales coupling the intersection of class, race, gender and geography with that of virtue, intelligence, ambition and belonging. The entrenched caricatures upon which such hatreds are predicated are promulgated not only in the sphere of popular culture, but by certain strands of academic scholarship, most notably by sociologist Thomas Sowell, who posits in an astonishing thesis entitled "Black Rednecks and White Liberals" that not only are the alleged "traits" of rural rednecks and urban blacks (laziness, promiscuity, violence, emotiveness) real, demonstrable, ingrained behaviours, they are linked historically-a cultural hangover nurtured in the liminal edge-spaces of British empire before the English "civilized" the outlaws living on its most immediate borders, then imported by the Scots-Irish to Appalachia and adopted by the descendants of slaves, who then brought this degraded "culture" with them to America's cities (Sowell 1995). "Black Rednecks and White Liberals," which historian James B. Stewart calls "the latest salvo in Thomas Sowell's continuing crusade to represent allegedly dysfunctional value orientations and behavioral characteristics of African Americans as the principal reasons for persistent economic and social disparities" (Stewart 2006), is culture-of-poverty theory in overdrive, not merely reifying the constructions it takes for granted through uncritically cited, highly selective historical "evidence," but fetishizing them as an explanation for the social exclusion of both poor urban blacks and poor rural whites in the present day.

So yes, rednecks may be a bit bitter. But if they're bitter about being steamrolled by the new economy, and bitter about being the perennial recipients of urban America's schizophrenic love-hate rural psychosis, they're also bitter about mainstream America's persistent, obstinate, hypocritical misinterpretation of their beliefs, values and motivations. I'll invoke the one example that seems to raise urban hackles more than any other. The incessant harping about Sarah Palin as a "gun-toting" redneck, an epithet which has ricocheted from sea to shining sea, is a 
case in point. Rural Americans don't "cling to guns" because of some facile, uniform bitterness about the economy. Some hold fast to the right to bear arms out of a dehistoricized interpretation of the Second Amendment, a dedication to vigilantism, or a bunker-like defense of private property, but many keep guns because they hunt, and consider other justifications to be secondary or altogether unimportant. And while hunting is a concept inimical to the impeccably manicured Maureen Dowds of the world, whose rump roast is delivered in a neat plastic package hundreds of miles from the industrial farm where it was raised under brutal conditions, it shouldn't be entirely distasteful to a nation of leather-clad carnivores which consumes, in various forms, several billion animals per year. Sometimes, like the Palins, rural people hunt for the sake of pleasure or tradition, and neither justification is far removed from that which urban and suburban Americans use to explain their Thanksgiving dinner. But hunting can play a more fundamental role in marginal rural economies as well. Anthropologist Hansen (1995) found that hunting as part of a broader subsistence strategy provided a crucial buffer against the exigencies of recession for Catskills rednecks, affording them a layer of protection against capitalistic crisis unavailable to the debt-laden middle-class exurbanites who have colonized the mountains, fleeing rising New York City rents and stagnant urban wages. Here, tradition mixes with expedience. For many rural hunters no longer economically dependent upon such an immediate culling of value from nature, hunting has been passed down from kin who were so dependent once, a way of maintaining ritualistic ties with family tradition and a practical defense against hard times to come.

Some commentators have taken issue with Palin's support of aerial hunting of endangered species - a legitimate point of debate - but most seem repulsed by the mere idea of hunting itself, especially with a woman behind the site. Yet the palaver over Palin's specific hunting practices has failed to raise any national conversation about the general conditions of humane animal consumption, a topic of intense concern among the hunters I've known through my rural research and my rural childhood. And while I don't hunt myself, there have been times when I've wished I did have the skill and equipment, like when I've side-swiped a white-tail that leaped in front of my truck on a dark lonely Adirondack highway and hobbled off into the forest, badly injured but alive. And I appreciated that I could stop at the corner Adirondack gas station and have the Big Gulp operator put in a quick call to some local hunters, who trudged out in the middle of the night to track the animal, assess the damage, and put the doe down instead of leaving her to suffer a slow, agonizing death. Of course, not all hunters are ardent conservationists, but from my experience in the North Country, the ones who blast the bejeezus out of anything moving with no concern beyond their own trophy wall are aspiring rednecks from urban New Jersey who see hunting as an opportunity to build up some Teddy Roosevelt-style masculine street cred, whatever the cost to the rural communities, human and animal, from which they extract such psychological value.

Daily encounters with wildlife are something most urban and suburban Americans leave happily to the province of exterminators and dogcatchers-or to rural Americans themselves, when they head out of town to drop off the puppy or kitten which seemed like a good idea at Christmastime but quickly became an 
unwanted burden easily disposed on a back rural route. My eldest brother, a diesel mechanic and lifelong hunter, has rescued countless cast-off pets from the woods surrounding our redneck dirt road that would otherwise have died a miserable death in the wilderness. He once spent a whole spring trapping and rehousing a litter of tame rabbits that some city dweller tossed out the car window in a sack. That was 20 years ago, and it's been the same story every year since. This last summer he and his wife, a nurse's aide at the county infirmary, dragged six mewling kittens out of the bush and paid to have them spayed and vaccinated out of their antediluvian rural salaries, like the gun-toting, nature-hating rednecks they are. While such mundane stories don't make good copy for the national press while the rural petit-bourgeoisie are shooting polar bears from helicopters, they matter a great deal to the rural Americans who live them out, year after year. A lot of rural bitterness might be alleviated if urban Americans would save their sage advice on hunting until such time as they've sorted their own relationships with animals, and stopped imagining that because there are six degrees of separation between their Sunday roast and their dinner table, they've somehow taken the high road. It's urban liberal hypocrisy, more than anything, that makes rural people bitter. The chroniclers of Sarah Palin's redneck crimes are dripping with it. Botoxed, Vogue-subscribing, Sex and the City junkies sneering at small-town Maybelline beauty queens; organic, free range meat champions pointing the finger at rural hunters; urban folk revivalist Dylan fans who look down their rarefied noses at the pawns in the game; retiree environmentalists who snap up Montana ranch land and brand every corner with a neon posted sign, coke-addled urban professionals who snort themselves stupid while revelling in the retro-chic of Trailer Park Boys and Cops. All those who are so preoccupied pointing out the hypocrisy of the white rural working class - the abstinence-preachers whose teenage daughters get knocked up, the Bible-thumping fundamentalists who despise Muslims, the government-hating farmers who rely on federal subsidies-that they can't be bothered to take stock of their own ironic positions.

However predictable the shopworn discourse of redneck-reviling has become, still the election produced a few unusual twists. After the Republican defeat, Palin's own campaign turned snake-like on her on the same grounds as her liberal detractors, one McCain aide describing the Palin family as "Wasilla hillbillies looting Neiman Marcus from coast to coast" in the wake of the wardrobe scandal (Newsweek 2008). Some rednecks themselves defied popular expectation and stumped for the Democratic ticket, organizing a widely publicized (especially by the Obama-Biden campaign) "Rednecks for Obama" drive around the slogan "Working for the man who will do more for the working man" (Rednecks for Obama 2008), while a lone redneck called "Cupcake" (Jason Hill), sporting a NASCAR cap and rebel flag tattoo, was interviewed by the BBC while handing out Obama stickers by the side of the road (Price 2008). And in perhaps the greatest irony of this historic election, America seems to have voted in white trash after all. Pastor James David Manning, the ardent Hillary Clinton supporter and Harlem antigentrification activist, lambasted Barack Obama himself as "trash" for being the son of a "white trash mother" (anthropologist Ann Soetoro) who bore him out of wedlock (YouTube 2008). More recently, an Irish band penned a song ("O'Leary, O'Reilly, O'Hare and O'Hara, there's no-one as Irish as Barack O'bama”) after 
tracing Obama's maternal kin line to Ireland, that fabled ancestral home of America's hillbillies (BBC 2008). The purported origin of Obama's great-greatgreat grandfather (shoemaker Fulmouth Kearney), Moneygall in County Offaly, has even invited the town's newly discovered favourite son home for a pint, which Obama tentatively accepted on the campaign trail (Simpson 2008). Muslim and Christian, black and white, Kenyan and Irish, Hawaiian and Chicagoan, Harvard intellectual and poor white trash-if identity makes the politician, then perhaps Barack Obama really is a president for us all.

Despite his landmark victories in Virginia and North Carolina, the final demise of the Southern Strategy-widely proclaimed in the wake of Obama's win-is by no means a foregone conclusion, and thus far seems largely predicated upon demographic forecasts, according to which the legacy of herrenvolk democracy will be literally bred out of the countryside as America becomes progressively less white, rather than falling to a concerted effort by the American left to change white rural attitudes (Rosenberg 2008). Indeed, as far as the popular left goes, rural America has many nuanced interpreters but few vocal defenders. The enormous promise of Jim Goad, at turns brilliant and idiotic author of The Redneck Manifesto (1997), has dissolved in an acid bath of misogyny and racism that makes me wake in a cold sweat at the horrific thought that this, at the last, is our Trotsky. Rural America today finds its most visible champions in music, and especially country music-Emmylou Harris singing of red dirt girls, Steve Earle invoking the oxycontin blues, the Dixie Chicks chronicling small-town marriages and the Earls that plague them. Despite Obama's minor victory in scoring a cleverly couched endorsement by bluegrass legend Ralph Stanley (Rolling Stone 2008), his campaign made little effort to win hearts and minds in places like Appalachia, and indeed the Democratic Party has all but abandoned rural American concerns in presidential elections, as Dee Davis of the Center for Rural Strategies noted in the pages of Salon: "Maybe the party that once welcomed Appalachian coal miners and hillside farmers has moved on. The national Democratic Party has become younger, richer, hipper and far less interested in preserving an identity forged in the Great Depression. Who really wants a political party full of poor mountaineers?" (Davis 2008). Yet the party's de facto relinquishment of the hinterlands could be causing it to turn a blind eye to potential political inroads into the heartland, the backwoods, and big sky country, where the Southern Strategy may be committing suicidethrough-irrelevance of its own accord.

A few weeks before the election finally came to its stunning close, I was struck by a photograph, published on multiple websites (Burkeman 2008), which seemed emblematic of both the enduring contradictions and improbable potentialities of small-town American politics. It showed an unassuming white house in Martinsville, Indiana, with a flagpole in the front yard. At the top of the pole, flew the Stars and Stripes. Just below that, the Confederate flag. And below, pushed into the lawn, an Obama-for-President sign. More a triumph of enthusiasm over apathy than a tortured compromise between conflicting racial commitments, this odd amalgam of symbolism was constructed by Brenda Livingstone (nurse, ordained minister, Republican and Obama supporter) and her husband Harold (gas station manager, atheist, political agnostic and rebel flag enthusiast). According to the local 
Martinsville Reporter-Times, which interviewed the couple after passersby kept stopping to snap photos (Hawkins 2008), the wife doesn't like the flag but respects her husband's right to free speech; the husband never follows presidential politics, but wasn't bothered by the sign. And I wondered how many more rural American stories belie, befuddle or break faith with the burlesques through which nonrural Americans make sense of our national birthplace. In the end, it is not Sarah Palin's politics I wish to defend-indeed there are few living politicians who speak to my brand of hillbilly socialism-but the right of redneck Americans to be considered real people, worthy of a good argument rather than reduced to a facile parody, heroic or demonic. And a good argument-an argument that pays attention to their precarious economic predicament as well as to their contradictory cultural identity, an argument that understands redneck from the inside-out, an argument that takes their lives seriously and challenges them to do the same for others, an argument that leaves caricature behind and wades fearlessly into complexity, kicking and a'gouging in the mud and the blood and the beer, in Johnny Cash's parlance-is what it will take to convince more of them that they don't need to settle for the fearmongering, bigoted right to represent their interests on the stage of national politics.

\section{References}

Anonymous. 2004. Fuck the South. http://tinyurl.com/3mmbx. Accessed 19 Nov 2008.

BBC. 2008 "Obama Irish" song is web hit. http://tinyurl.com/67h8pk. Accessed 4 Jan 2009.

Billings, Dwight B., Gurney Norman, and Katherine Ledford (eds.). 1999. Confronting Appalachian stereotypes: Back talk from an American region. Lexington: University of Kentucky Press.

Burkeman, Oliver. 2008. Signs of the times. http://tinyurl.com/8lyjbk. Accessed 4 Jan 2009.

Carr, Duane. 1996. A question of class: The redneck stereotype in southern fiction. Green: Bowling Green State University Popular Press.

Collins, Gail. 2008a. McCain's grizzly politics. New York Times. OpEd Section, September 6. http://tinyurl.com/9vfgpg. Accessed 19 Nov 2008.

Collins, Gail. 2008b. McCain's Baked Alaska. New York Times. OpEd Section, August 30. http://tinyurl.com/6h6nqw. Accessed 19 Nov 2008.

Collins, Gail. 2008c. Sarah Palin Speaks! New York Times. OpEd Section, September 4. http://tinyurl.com/6m7x5m. Accessed 9 Sept 2008.

Davis, Dee. 2008. Why don't those hillbillies like Obama? Salon. http://tinyurl.com/8bd5et. Accessed 8 Jan 2009.

Dionne, E.J. Jr. 2008. Northern underexposure. Washington Post. OpEd Section, September http://tinyurl.com/8jrbkr. Accessed 19 Nov 2008.

Dowd, Maureen. 2008. Vice in go-go boots? The New York Times. OpEd Section, 31 August. http://tinyurl.com/76dgeo. Accessed 22 Dec 2008.

Feldman, Gregory. 2005. Culture, State and Security in Europe: The case of citizenship and integration policy in Estonia. American Ethnologist 32 (4): 676-694.

Goad, Jim. 1997. The redneck manifesto. New York: Simon \& Schuster.

Hansen, Edward C. 1995. The Great Bambi War: Tocquevillians versus Keynesians in an Upstate New York County. In Articulating hidden histories: Exploring the influence of Eric R. Wolf, ed. Jane Schneider, and Rayna Rapp. Berkeley: University of California Press.

Harkins, Anthony. 2004. Hillbilly: A cultural history of an American Icon. New York: Oxford University Press.

Hartigan Jr., John. 1997. Unpopular culture: The case of "White Trash". Cultural Studies 11(2): 316343. 
Hawkins, Ronald. 2008. Confederate flag, Obama sign side by side. http://tinyurl.com/67ns81. Accessed 4 Jan 2009.

Huber, Patrick. 1995. A short history of Redneck: The fashioning of a southern white masculine identity. Southern Culture 1 (2): 144-166.

Huffington, Arianna. 2008. Sarah Palin: A Trojan Moose concealing four more years of George Bush. http://tinyurl.com/7ejd2p. Accessed 19 Nov 2008.

Jarosz, Lucy, and Victoria Lawson. 2002. "Sophisticated People versus Rednecks:" Economic restructuring and class difference in America's West. Antipode 34 (1): 8-27.

Jong, Erica. 2008. The Mary Poppins Syndrome. The Huffington Post. September 9. http://tinyurl.com/ 69cp55. Accessed 9 Sept 2008.

Newsweek. 2008. Hackers and spending sprees: Highlights from Newsweek's special election project. http://tinyurl.com/69hm3a. Accessed 4 Jan 2009.

Price, Matthew. 2008. Breaking stereotypes with cupcake. http://tinyurl.com/5wqpbq. Accessed 4 Jan 2009.

Rednecks for Obama. 2008. Rednecks for Obama. http://tinyurl.com/57vrf9. Accessed 4 Jan 2009.

Rich, Frank. 2008. Palin and McCain's shotgun marriage. New York Times. OpEd Section, September 7. http://tinyurl.com/5vcewx. Accessed 19 Nov 2008.

Rolling Stone. 2008. Bluegrass legend Ralph Stanley endorses Obama: "We Need a Change." Blogs Section, 3 October. http://tinyurl.com/4mutr9. Accessed 8 Jan 2009.

Rosenberg, Simon. 2008. On Obama, Race, and the End of the Southern Strategy. New democratic network. http://tinyurl.com/99d7dt. Accessed 9 Jan 2009.

Saxton, Alexander. 1990. The rise and fall of the White Republic: Class politics and mass culture in nineteenth-century America. London and New York: Verso.

Simpson Mark. 2008. Dublin invites O’bama back home. http://tinyurl.com/66rk44. Accessed 4 Jan 2009.

Slate, V. 2008. Postcards from Palin's hometown. http://tinyurl.com/6mxoph. Accessed 22 Dec 2008, $10: 15$.

Sowell, Thomas. 2005. Black rednecks and white liberals. San Francisco: Encounter Books.

Stewart, James B. 2006. Thomas Sowell's quixotic quest to denigrate African American culture: A critique. Journal of African American History 91: 328-334.

Stock, Catherine McNicol. 1996. Rural radicals: Righteous rage in the American grain. Ithaca: Cornell University Press.

Wilson, Jacqueline Zara. 2002. Invisible racism: The language and ontology of "White Trash". Critique of Anthropology 22(4): 387-401.

Wray, Matt, and Annalee Newitz (eds.). 1997. White trash: Race and class in America. New York: Routledge.

YouTube. 2008. Obama is white trash documented proof. http://tinyurl.com/8xu38v. Accessed 4 Jan 2009. 